the equator than Salisbury in Rhodesia. The importance of a low latitude has been illustrated by the success of Helwan Observatory in obtaining the earliest photograph of Halley's comet, owing to the longer night near Cairo in summer as compared with Greenwich or Heidelberg. This advantage would be still further marked in the case of Khartoum, some $14^{\frac{1}{4}}$ south of Helwan, or relatively about as far as Barcelona is from Edinburgh.

Altitude.-Precise determinations have been made by levelling, and the land near the river has been found to stand about $3^{8} 5$ metres above sea-level.

Climate.-So far as I am aware, the " seeing " qualities of the atmosphere have not been tested. Ordinary experience shows that it is remarkably clear, and it is no uncommon thing near the Italian boundary in these latitudes to see Jebel Kassala (4400 feet) and some of the Eritrean hills at distances up to a hundred miles. These districts are at no great height above sea-level, and the clearness of vision must in large measure be due to the pureness and homogeneity of the air.

Relative humidity is a factor presumably of great importance as regards the "seeing" qualities of the air; and those interested may refer to Captain Lyons's "Physiography of the Nile and its Basin," where they will find the data for Khartoum and many other stations concisely summarised. More recent data are available in the annual meteorological reports, \&c., published by the Egyptian Survey Department. Suffice it to say that the mean annual relative humidity is $3 \mathrm{I}$ per cent., and this figure is only exceeded for three months in the year. The Khartoum observations have been made within a short distance of the river, and no doubt the humidity results are higher than would have been obtained at a station a mile or two away. The air is often dry enough, even near the river, to desiccate moist calcium chloride. There are very few cloudy nights.

During the summer months violent dust-storms occur, but these are generally of short duration. Situated on the southern edge of the desert, it has a rainfall of about 6 inches a year, almost confined to the months of August and September. Temperature conditions are extreme, but owing to the intense dryness heat is seldom oppressive to the individual.

Communication.-Several mails a week carry letters to London in nine or ten days, and the outward journey can be done in eight and a half days. The railway to the Red Sea enables goods from outside to reach Khartoum with only a single handling at Port Sudan.

It seems improbable that there is any other locality in an equally low latitude offering the advantages of a clear, dry atmosphere combined with a fair altitude and such ready means of communication with European centres of learning. As an actual site in this vicinity the Abu Meru Hills may be suggested, as rising about roo metres above the river at a distance of some eight miles north-west from Omdurman. The place is far enough to avoid any local humidity due to the river, as well as the dust-raising traffic converging on the towns. The prevalent winds are from the north and north-west, and traverse hundreds of miles of unbroken desert before reaching the hills.

In conclusion, I have to thank $\mathrm{Mr}$. Rolston for directing $m y$ attention to the search being undertaken by the French Geographical Society. Our friends across the Channel have extensive possessions in northern Africa, and no doubt these have first claim for consideration; but if they are unable to exploit Khartoum, perhaps it may be kept in view and tested when munificence can be found to provide for the equipment and maintenance of a new observatory.

Khartoum, Sudan, October ${ }_{5}$.

\section{The Scientific Misappropriation of Popular Terms.}

I entirely agree with Dr. Harmer (Nature, October 26) that the extension of priority to groups larger than genera is undesirable, and the use of the word insect should be judged solely by practical convenience.

If the restricted use of the word insect were as generally accepted as that of deer there would be no objection to its use. I understand, however, that the use of deer for small mammals was abandoned in Middle English, and that the phrase " mice and rats and such small deer," quoted by Dr. Harmer, was intended by Shakespeare and later authors to be a joke, like the railway porter's classification of the tortoise as an insect.

The same explanation is not available for the remark in Prof. Adam Sedgwick's "Text-book of Zoology" (vol. i., p. 502) that "all spiders are predaceous and suck the juices of other insects."

I cannot agree with Dr. Harmer that the word insect is, or ever has been, generally used in the restricted sense either in popular literature or in technical works other than zoological. For example, agriculturists always seem to speak of insect in the wider sense, and agricultural literature generally does the same. Nor do I find any agreement on the subject among zoologists, and the tendency seems to be for them to abandon Insecta as a class name in favour of Hexapoda. Sir Ray Lankester expresses the matter admirably in the new edition of the "Encyclopædia Britannica." He rejects Insecta as the class name of the "so-called 'true insects," " and regrets that Lamarck, who invented the "very appropriate name Hexapoda," did not insist on it; and "so the class of Pterygote Hexapods came to retain the group-name Insecta, which is, historically or etymologically, no more appropriate to them than it is to the classes Crustacea and Arachnida." He refers with obvious disapproval to " the tendency to retain the original name of an old and comprehensive group for one of the fragments into which such group becomes divided by the advance of knowledge, instead of keeping the name for its logical use as a comprehensive term, including the new divisions, each duly provided with a new name" (Sir Ray Lankester, "Encyclop. Brit.," vol. ii., I910, p. 673).

Those, therefore, who use the word insect in its older and etymologically more correct sense have the support of high zoological authorities.

4 Park Quadrant, Glasgow, October 28.

\section{The Colour of a Donkey.}

ON October 5 , at 7 p.m., the moon being high up and almost obscured by a thick high haze, giving a diffused ground light with no shadows, I was crossing an open field by a footpath. The field is about a quarter of a mile across, and the hedges all round it, with tall elms, were marked out in broad dark masses. The grass, dried by the hot summer, is straggly and grey, with short green undergrowth. There were a number of cows-red and red and white-scattered over the field, visible in the dim light up to 80 yards by measurement. One could apparently see everything within that radius.

I was brought to a halt by hearing an absolutely invisible animal noisily cropping the grass a few feet away. On going nearer I found a grey donkey. On his starboard quarter at 4 yards' distance his dark head appeared as a moving blur, but "stern on" at that distance he was completely invisible-an " airy nothing"-though, like Folonius, " at supper." It was most extraordinary to hear the animai feeding and to be unable to see a vestige of him. At 2 yards' distance he was a mere ghost. The lighter under-colour of the veniral surface certainly diffused what light there was, after the manner of the vanishing duck in the Oxford Museum. That may be partly the explanation.

Returning by the same path at $7 \cdot 30$, I tried by walking across the field in every direction to find the donkey, but failed, though the cows were all plainly visible, feeding or lying down, and the donkey was in the field all night.

The striped zebra, invisible in the moonlight, is cited as an example of protective coloration. I merely record the above facts without venturing upon any explanation of them.

There is an old rhyme describing the palpitations of a villager followed at night across a field by an invisible creature with audible footsteps-

$$
\text { "And much he feared that dreadful ghost }
$$

That was also a donkey, and the rhyme, like Gilpin's ride, may be the jocular record of a fact. My donkey was ghostly enough, and suggests possibilities.

Waterstock, October 24 .
E. C. SPICER.

กก. 2 I92, VOL. 88] 